G.V. Bezprozvannych, I.A. Kostiukov

\title{
A CALCULATION MODEL FOR DETERMINATION OF IMPEDANCE OF POWER HIGH VOLTAGE SINGLE-CORE CABLES WITH POLYMER INSULATION
}

\begin{abstract}
Introduction. The wave parameters of power cables with polymer insulation differ significantly from the parameters of overhead lines and power transformers. As a result, there are more and more objects in electrical networks for which the occurrence of complex multi frequency transients, accompanied by dangerous overvoltages, should be expected. Purpose. To develop a computational model of the complex impedance of high-voltage single-core power cables of coaxial design required to determine the frequency dependencies of the active resistance and inductance of the conductive core and metal shield, taking into account the surface effect and proximity effect. Methodology. The method is based on solving a system of linear algebraic Kirchhoff equations (SLAE) for magnetically coupled contours. SLAE can be used to calculate conductors taking into account the skin effect and proximity effect. Practical value. The developed model is the basis for determining the characteristic impedance of high-voltage single-core power cables in a wide range of frequencies required to establish adequate criteria for evaluating the parameters of high-frequency effects critical for cross linked polyethylene insulation. References 16, table 1, figures 7 .

Key words: power cables, complex resistance, magnetically coupled circuits, system of linear algebraic equations, conductor, screen, coefficient of irregularity of current distribution.
\end{abstract}

Запропонована чисельна розрахункова модель визначення активного опору та індуктивності струмопровідної жили й металевого екрану силових одножильних кабелів коаксіальної конструкиї̈ з урахуванням поверхневого ефекту та ефекту близькості в широкому діапазоні частоти. Виконано в залежності від частоти порівняння коефіцієнтів нерівномірності розподілу струму по перетину струмопровідної жили кабелю. Показано, ще збільщення товщини мідного екрану призводить до збільшення коефічієнта нерівномірності розподілу струму по перерізу екрану та активного опору кабелю

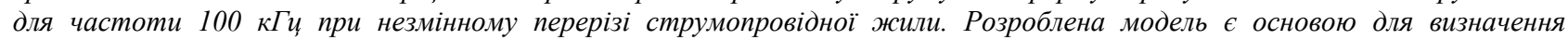
характеристичного імпедансу силових високовольтних одножильних кабелів в широкому діапазоні частоти, необхідного для встановлення адекватних критеріїв очінки параметрів високочастотних впливів, критичних для зшитої поліетиленової ізолячії. Бібл. 16, табл. 1, рис. 7.

Ключові слова: силові кабелі, комплексний опір, магнітозв'язані контури, система лінійних алгебраїчних рівнянь, струмопровід, екран, коефіціснт нерівності розподілу струму.

Предложена численная расчетная модель определения активного сопротивления и индуктивности токопроводящей жиль и экрана силовых одножильных кабелей коаксиальной конструкции с учетом поверхностного эффекта и эффекта близости в широком диапазоне частоты. Выполнено в зависимости от частоты сравнение коэффициентов неравномерности распределения тока по сечению токопровода. Показано, что увеличение толщины медного экрана приводит к увеличению коэффициента неравномерности распределения тока по сечению экрана и активного сопротивления кабеля для частоты 100 кГи при неизменном сечении токопроводящей жиль. Разработанная модель является основой для определения характеристического импеданса силовых высоковольтных одножильных кабелей в широком диапазоне частоты, необходимого для установления адекватных критериев оценки параметров высокочастотных воздействий, критичных для сшитой полиэтиленовой изоляции. Библ. 16, табл. 1, рис. 7.

Ключевые слова: силовые кабели, комплексное сопротивление, магнитосвязанные контуры, система линейных алгебраических уравнений, токопровод, экран, коэффициент неравномерности распределения тока.

Introduction. High-voltage power cables with thermosetting polyethylene insulation are critical components of power systems. Many investments are made in their production to ensure reliable operation [1-3]. Power high-voltage cables with insulation based on cross-linked polyethylene with voltage of $6-500 \mathrm{kV}$ are characterized by increased values of electrical capacitance and reduced values of impedance (characteristic impedance) compared to cables with paper-impregnated insulation [4-8]. As a result, there are more and more objects in electrical networks for which complex multifrequency transients should be expected, which are accompanied by dangerous overvoltages and currents [5-8]. The values of overvoltage and the duration of the transient are determined by the length of the cable line and the impedance of the high-voltage power cable. The duration of transients is tens and hundreds of microseconds, which corresponds to the frequency of such processes from units to tens and hundreds of kilohertz [9]. High-frequency components of current and voltage accelerate, in particular, the development of water treeings in polymer insulation and can cause the development of electrical treeings, i.e. loss of electrical insulation strength of high-voltage power cables [10,11]. The development of adequate criteria for assessing the parameters of high-frequency effects critical for crosslinked polyethylene insulation of high-voltage cables is based on monitoring of the electrical insulation state during operation, including the results of temporal reflectometry, which requires data on the complex resistance of conductive core and screen to determine the characteristic impedance of the power cable [12].

The normative and technical documentation gives the values of the resistance of the current-carrying core at DC at temperature of $20{ }^{\circ} \mathrm{C}$ and the inductance of the power single-core high-voltage cable of coaxial design depending on the spatial location in a three-phase cable line (triangle or plane) [2]. To determine the active resistance of the core during the flow of $\mathrm{AC}$ with frequency of $50 \mathrm{~Hz}$, mathematical expressions are given 
that approximate the dependence of resistance due to the skin effect and the proximity effect of adjacent singlecore cables $[2,13]$.

In [14] the analytical model of calculation of longitudinal complex resistance taking into account the proximity effect for a current-carrying core and inductance of a core and the metal screen without taking into account influence of frequency of a single-core power cable is presented. In [15], the intrinsic inductance of the metal screen is determined under the assumption of uniform distribution of the induced current in the screen of a single-core power cable.

Thus, obtaining the frequency dependencies of the active resistance and inductance of current-carrying cores and metal shields of high-voltage single-core power cables, taking into account the skin effect and proximity effect is an important and urgent problem, which until recently is insufficiently developed.

The goal of the research is to develop a computational model of complex resistance of highvoltage single-core power cables of coaxial design, necessary to determine the frequency dependencies of active resistance and inductance of conductive core and metal screen taking into account the skin effect and the proximity effect.

Numerical determination of the active resistance and inductance of the current line, taking into account the skin effect and the proximity effect. Divide the conductor into a number of parallel branches (Fig. 1) current filaments. Each $i$-th branch has an active resistance $R_{i}$ and an inductance $L_{i}$, and due to the magnetic field is connected to the $j$-th branch. The mutual inductance between the $i$-th and the $j$-th branches is denoted as $M_{i j}$.

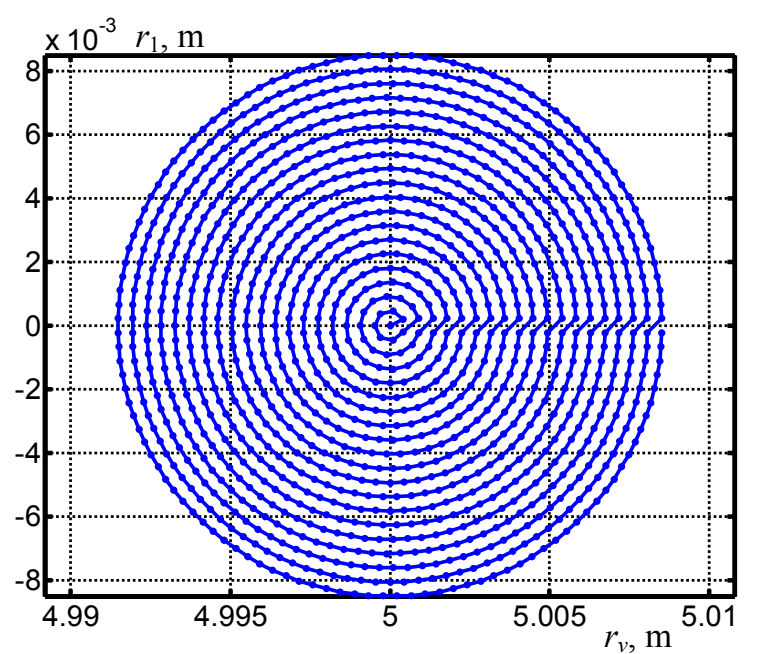

Fig. 1. Layout of nodes along the cross section of the current line. The first node is in the center of the current line, the others are located radially. The line connecting the nodes determines the numbering order - counterclockwise

Suppose that in the $i$-th branch there is a source of variable electromotive force EMF $E_{i}$ of frequency $f$. Then for the closed contour of this branch we write the Kirchhoff equation:

$$
\left(R_{i}+j \omega L_{i}\right) \cdot \dot{I}_{i}+\sum_{j \neq i}^{N_{1}}\left(j \omega M_{i j} \cdot \dot{I}_{j}\right)=\dot{E}_{i},
$$

where the first term $\left(R_{i}+j \omega L_{i}\right) \cdot \dot{I}_{i}$ determines the voltage drop on the active resistance and the intrinsic inductance of the $i$-th branch, and all other components $\sum_{j \neq i}^{N_{1}}\left(j \omega M_{i j} \cdot \dot{I}_{j}\right)$ are the voltage drops on the mutual inductance of the $i$-th branch with all other branches.

Equation (1) contains $N_{1}$ terms with unknown currents of parallel branches: $I_{1}, I_{2}, \ldots I_{i}, \ldots I_{j}, \ldots I_{N}$. For each of $N_{1}$ branches we write an equation similar to (1). We obtain a system of linear algebraic Kirchhoff equations (SLAE):

$$
\left\{\begin{array}{c}
\left(R_{1}+j \omega L_{1}\right) \cdot \dot{I}_{1}+\sum_{j \neq 1}^{N_{1}}\left(j \omega M_{i j} \cdot \dot{I}_{j}\right)=\dot{E}_{1} ; \\
\left(R_{2}+j \omega L_{2}\right) \cdot \dot{I}_{2}+\sum_{j \neq 2}^{N_{1}}\left(j \omega M_{i j} \cdot \dot{I}_{j}\right)=\dot{E}_{2} ; \\
\ldots \\
\left(R_{N 1}+j \omega L_{N 1}\right) \cdot \dot{I}_{N 1}+\sum_{j \neq N 1}^{N_{1}}\left(j \omega M_{i j} \cdot \dot{I}_{j}\right)=\dot{E}_{N 1} .
\end{array}\right.
$$

Write SLAE (2) in matrix form:

$$
\left(\begin{array}{cccc}
\left(R_{1}+j \omega L_{1}\right) & j \omega M_{12} & \cdots & j \omega M_{1, N} \\
j \omega M_{21} & \left(R_{2}+j \omega L_{2}\right) & \cdots & j \omega M_{2, N} \\
\ldots & & & \ldots \\
j \omega M_{N, 1} & j \omega M_{N, 2} & \cdots & \left(R_{N}+j \omega L_{N}\right.
\end{array}\right) \cdot\left(\begin{array}{l}
\dot{I}_{1} \\
\dot{I}_{2} \\
\ldots \\
\dot{I}_{N}
\end{array}\right)=\left(\begin{array}{l}
\dot{E}_{1} \\
\dot{E}_{2} \\
\ldots \\
\dot{E}_{N}
\end{array}\right) .(3)
$$

On the diagonal of the matrix of SLAE coefficients (3) there are the intrinsic resistances of the branches (active and inductive), outside the diagonal - the mutual inductive resistances of the branches.

In some cases, the values of EMF acting in the branches of the current line are the same $-\dot{E}_{S}$. Then SLAE (3) takes the form:

$$
\left(\begin{array}{cccc}
\left(R_{1}+j \omega L_{1}\right) & j \omega M_{12} & \cdots & j \omega M_{1, N} \\
j \omega M_{21} & \left(R_{2}+j \omega L_{2}\right) & \cdots & j \omega M_{2, N} \\
\ldots & & & \cdots \\
j \omega M_{N, 1} & j \omega M_{N, 2} & \cdots & \left(R_{N}+j \omega L_{N}\right)
\end{array}\right) \cdot\left(\begin{array}{c}
\dot{I}_{1} \\
\dot{I}_{2} \\
\cdots \\
\dot{I}_{N}
\end{array}\right)=\left(\begin{array}{c}
\dot{E}_{S} \\
\dot{E}_{S} \\
\cdots \\
\dot{E}_{S}
\end{array}\right) .
$$

SLAE (4) allows to determine the parameters of the complex resistance of current lines, taking into account the skin effect and the proximity effect.

The mutual inductance $M_{12}$ between two coaxial ring contours with currents is calculated based on the analytical formula [16]:

$$
M_{12}=2 \mu \mu_{0} \sqrt{r_{1} \cdot r_{2}} \cdot \frac{1}{k} \cdot\left[\left(1-\frac{k^{2}}{2}\right) K(k)-E(k)\right],
$$

where $r_{1}, r_{2}$ are the radii of the current lines (for singlephase power cable of coaxial design $r_{1}$ is the radius of the current-carrying core; $r_{2}$ is the inner radius of the metal cable screen, respectively); $k=\sqrt{\frac{4 r_{1} r_{2}}{\left(r_{1}+r_{2}\right)^{2}+G^{2}}}$; where $G$ 
is the distance between the planes of the current lines along the axis of symmetry; $K(k)$ and $E(k)$ are functions of complete elliptic integrals of the first and second kind:

$$
K(k)=\int_{0}^{\pi / 2} \frac{d \beta}{\sqrt{1-k^{2} \sin ^{2} \beta}} ; E(k)=\int_{0}^{\pi / 2} \sqrt{1-k^{2} \sin ^{2} \beta} \cdot d \beta .
$$

The intrinsic inductance of a circular conductor of massive cross-section is calculated as the mutual inductance between two filamentary conductors of the same radius, located at a distance $G$ from each other.

For a circular section of radius $r$, the geometric mean distance of the area of the circle from itself $G$ is equal to:

$$
G=\frac{r}{\sqrt[4]{e}}
$$

where $e=2.71828 \ldots$ is the basis of natural logarithms.

As a result of solution (4), the currents in the branches $I$ and the total current $I_{\Sigma}$ of all parallel branches of the current line are determined.

After finding the total current of all parallel branches, the total complex resistance, its active $R$ and reactive $X_{L}$ components, the equivalent inductance $L$ of the current line are determined:

$$
\dot{Z}=\frac{\dot{E}_{s}}{\dot{I}_{\Sigma} \cdot 2 \pi r_{v}}, \quad R=\operatorname{Re}(\dot{Z}), \quad X_{L}=\operatorname{Im}(\dot{Z}), \quad L=\frac{X_{L}}{\omega},
$$

where $r_{v}$ is the bending radius of the current line.

Results of numerical modelling. The axis of symmetry of the annular current line (Fig. 1) is on the left at a distance $Z$ from the center of the current line. Passing the nodes in each layer begins on the outside of the annular current line, then passes on the inside and returns to the outside. The current tends to pass along the path of the smallest length (on the inner side of the current line), due to which its density is higher there (Fig. 1).

Figures 2-4 show the effect of frequency on the distribution of currents $I$ in branches $N$ (Fig. 2), active resistance $R_{c}$ (Fig. 3), equivalent inductance $L_{c}$ (Fig. 4) of a copper conductive core of a power cable with a cross section of $240 \mathrm{~mm}^{2}$ (Fig. 2,a; curves 1 in Fig. 3, 4) and $800 \mathrm{~mm}^{2}$ (Fig. 2,b; curves 2 in Fig. 3, 4), respectively.

With increasing frequency, the displacement of current on the surface of the current line increases. As a result, the effective resistance of the current line increases (Fig. 3).

Figure 5 shows a layout of the location of the nodes at the intersection of the conductive core and the screen of the power single-core cable of coaxial structure. The results of numerical calculation of frequency-dependent active resistance and inductance $L$ of the power cable with voltage of $110 \mathrm{kV}$ with a cross section of a copper conductive core of $240 \mathrm{~mm}^{2}$ and a copper screen with thickness of $1 \mathrm{~mm}$ are shown in Fig. 6, 7, respectively. The active resistance of the cable $R$ consists of the resistance of the conductive core $R_{c}$ and the metal screen $R_{s}: R=R_{c}+R_{s}$. The equivalent inductance of the cable $L$ includes the equivalent inductance of the conductive core $L_{c}$, the equivalent screen inductance $L_{s}$ and the mutual inductance between core and screen.
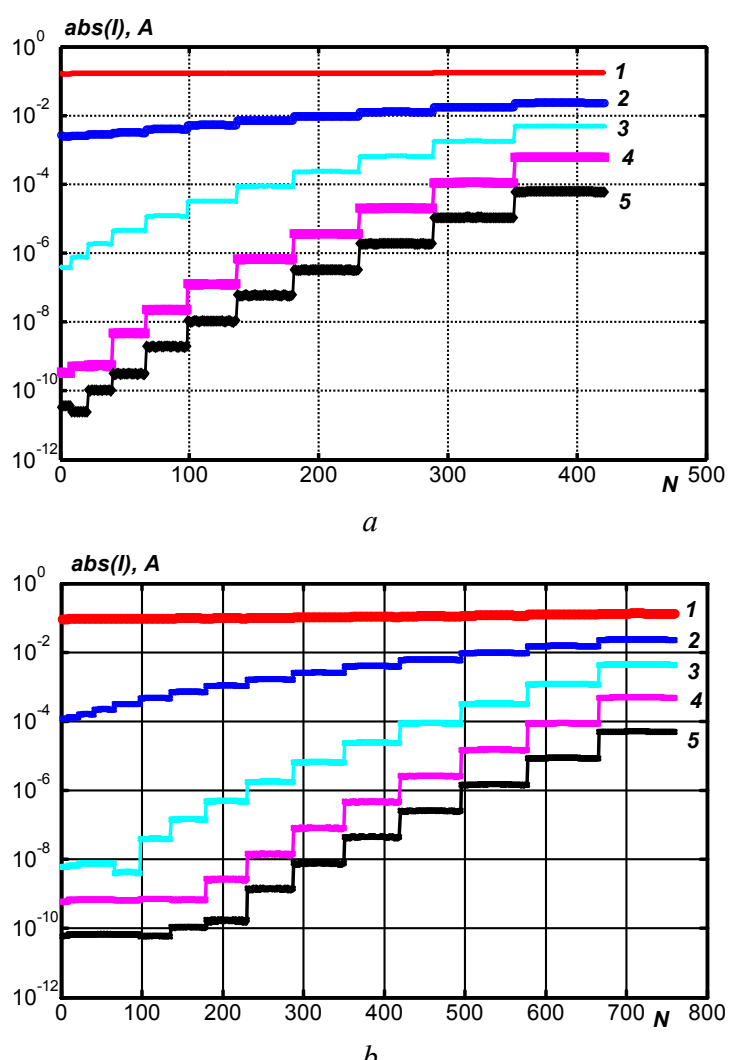

Fig. 2. Influence of frequency on current distribution on branches $N$ of the power current line (curve 1 - frequency 50 $\mathrm{Hz}$, curve $2-1 \mathrm{kHz}$, curve $3-10 \mathrm{kHz}$, curve $4-100 \mathrm{kHz}$, curve $5-1 \mathrm{MHz}$ )

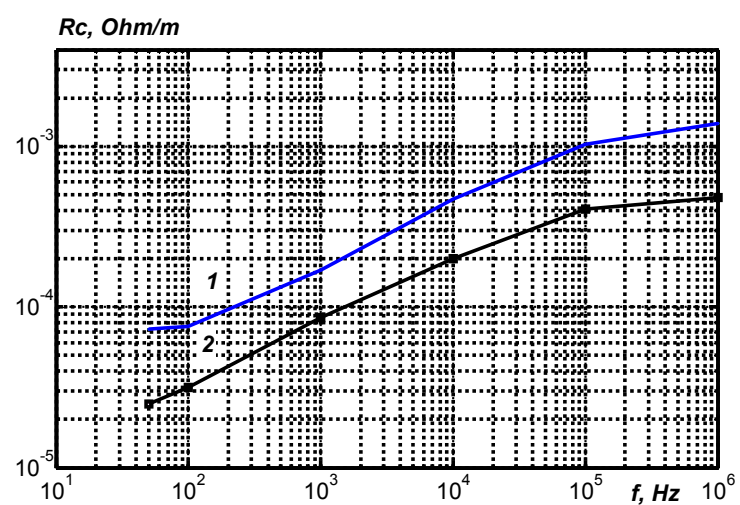

Fig. 3. Frequency dependencies of active resistance of copper power current line

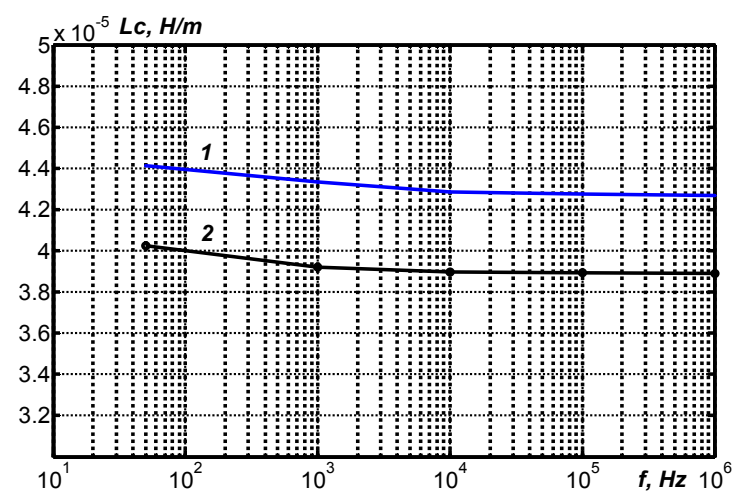

Fig. 4. Frequency dependencies of equivalent inductance of copper power current line 


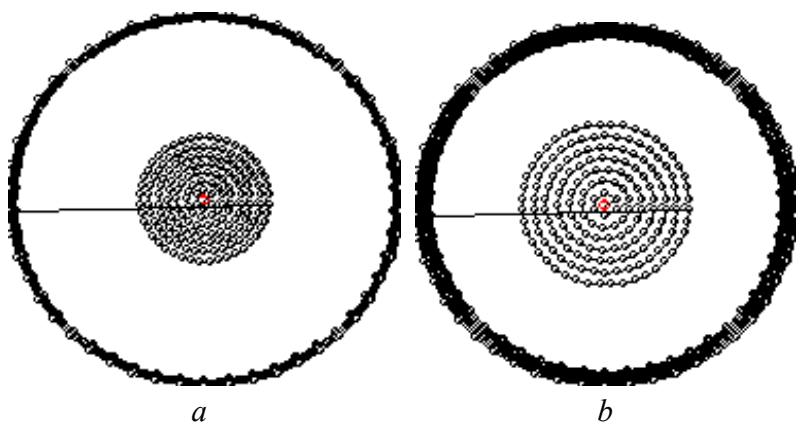

Fig. 5. Layout of the nodes at the intersection of the conductive core and the screen with thickness of $1 \mathrm{~mm}(a)$ and $3 \mathrm{~mm}(b)$

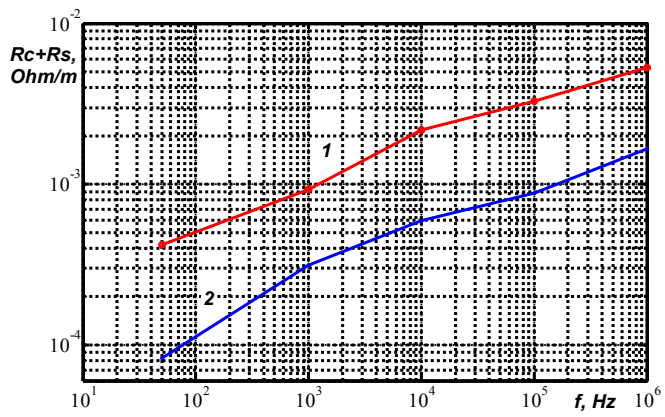

Fig. 6. Frequency dependence of the active resistance of a power cable of single-core design of voltage of $110 \mathrm{kV}$

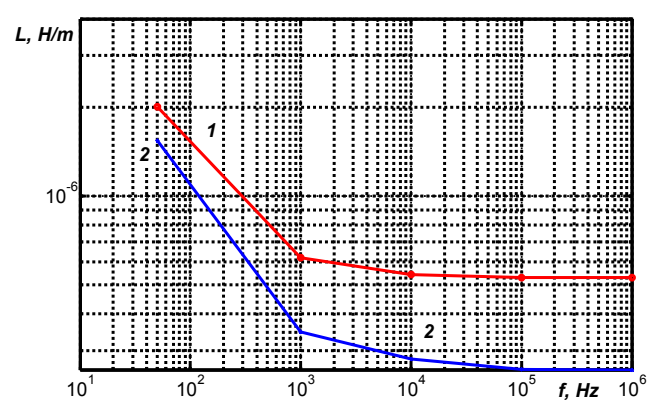

Fig. 7. Frequency dependence of the equivalent inductance of a power cable of single-core design of voltage of $110 \mathrm{kV}$

Increase the thickness of the copper screen 3 times (from 1 to $3 \mathrm{~mm}$ ) leads to an increase in the coefficient of non-uniformity of current distribution across the screen by 1.25 and 4.48 times with constant value of the coefficient of non-uniformity of current distribution across the copper core section for frequency of $1 \mathrm{kHz}$ and $100 \mathrm{kHz}$, respectively. For frequency of $1 \mathrm{kHz}$, the active resistance of a cable with a screen of smaller thickness is 1.4 times the active resistance of a cable with a screen of thicker thickness.

Checking the reliability of the results of numerical calculations is performed on the basis of comparing the coefficients of non-uniformity of the current distribution due to the skin effect and the proximity effect, along the cross section of the current line.

The first coefficient $K_{f}$ is calculated through the ratio of heat output at $\mathrm{AC}$ and DC. The power of heat dissipation at $\mathrm{AC}$ is determined by the total power of heat dissipation of parallel branches taking into account the redistribution of current along the cross section of the conductive core. The power of heat dissipation at DC is determined by the uniform distribution of current across the cross section of the conductive core.
The second coefficient $K_{R}$ is calculated through the ratio of the resistance of the current line at AC and DC.

Table 1 shows a comparative analysis of the coefficients of non-uniformity of current distribution at the intersection of conductive copper cores. The results of the calculations are identical.

Table 1

Comparative analysis of the coefficients of non-uniformity of current distribution across the current line section

\begin{tabular}{|c|c|c|c|c|}
\hline \multirow{2}{*}{$\begin{array}{c}\text { Frequency, } \\
\mathrm{Hz}\end{array}$} & \multicolumn{2}{|c|}{$\begin{array}{c}\text { Cross section of the } \\
\text { copper current line } \\
240 \mathrm{~mm}^{2}\end{array}$} & \multicolumn{2}{|c|}{$\begin{array}{c}\text { Cross section of the } \\
\text { copper current line } \\
800 \mathrm{~mm}^{2}\end{array}$} \\
\cline { 2 - 5 } & $K_{f}$ & $K_{R}$ & $K_{f}$ & $K_{R}$ \\
\hline 50 & 1,0156 & 1,0156 & 1,1546 & 1,1545 \\
\hline 100 & 1,0605 & 1,0605 & 1,4598 & 1,4598 \\
\hline 1000 & 2,3581 & 2,3581 & 3,9658 & 3,9655 \\
\hline 10000 & 6,5865 & 6,5865 & 9,2692 & 9,2686 \\
\hline 100000 & 14,3079 & 14,3079 & 19,4337 & 19,4337 \\
\hline 1000000 & 19,4332 & 19,4332 & 22,2853 & 22,2836 \\
\hline
\end{tabular}

\section{Conclusions.}

For the first time, a computational numerical model for determining the complex resistance of high-voltage single-core power cables with polymer insulation is proposed, which allows to determine the active resistance and inductance of both conductive core and copper screen, taking into account the skin effect and proximity effect.

The developed model is the basis for determining the characteristic impedance of high-voltage single-core power cables in a wide range of frequencies required to establish adequate criteria for evaluating the parameters of high-frequency effects critical for cross-linked polyethylene insulation.

Based on the proposed computational numerical model, an appropriate technique can be developed to determine the frequency dependencies of the active resistance and inductance of a single-core power cable of coaxial design, which can be the basis for improving the accuracy of mathematical modelling of transients in cable lines arising at single-phase short circuits to the earth and other switchings in electric networks at bilateral grounding of the screen.

Conflict of interest. The authors declare that they have no conflicts of interest.

\section{REFERENCES}

1. Shidlovsky A.K., Shcherba A.A., Zolotarev V.M., Podoltsev A.D., Kucheryavaya I.N. Kabeli s polimernoi izoliatsiei na sverkhvysokie napriazheniia [EHV cables with polymer insulation]. Kyiv, Institute of Electrodynamics of the NAS of Ukraine Publ., 2013. 552 p. (Rus).

2. XLPE-insulated power cables for voltages from $45 \mathrm{kV}$ up to $330 \mathrm{kV}$. PJSC Yuzhcable Works, Kharkiv. Available at: https://yuzhcable.com.ua/wp-

content/uploads/2018/03/Catalogue-XLPE-cables-45-330kV.pdf (accessed 13 May 2020).

3. Bezprozvannych G.V. Zolotaryov V.M., Antonets Y.A. High voltage cable systems with integrated optical fiber for monitoring cable lines. 2020 IEEE KhPI Week on Advanced Technology (KhPIWeek), 2020, pp. 407-410. doi: https://doi.org/10.1109/KhPIWeek51551.2020.9250174. 
4. Wang H., Cao J., He Z., Yang J., Han Z., Chen G. Research on Overvoltage for XLPE Cable in a Modular Multilevel Converter HVDC Transmission System. IEEE Transactions on Power Delivery, 2016, vol. 31, no. 2, pp. 683-692. doi: https://doi.org/10.1109/TPWRD.2015.2469595.

5. Li J., Xu L., Chen X., Zhao A., Liu J., Zhao X., Deng J., Zhang G. Analysis of statistical and frequency characteristics of transient overvoltage of hybrid cable-OHL lines. 2018 China International Conference on Electricity Distribution (CICED), 2018, pp. 26502654. doi: https://doi.org/10.1109/CICED.2018.8592463.

6. Olsen R.G. Propagation along overhead transmission lines with multiply grounded shield wires. IEEE Transactions on Power Delivery, 2017, vol. 32, no. 2, pp. 789-798. doi: https://doi.org/10.1109/TPWRD.2016.2561977.

7. Zhao H., Zhang W., Wang Y. Characteristic Impedance Analysis of Medium-Voltage Underground Cables with Grounded Shields and Armors for Power Line Communication. Electronics, 2019, vol. 8, no. 5, p. 571. doi: https://doi.org/10.3390/electronics8050571.

8. Meng J., Wang W., Tang X., Xu X. Zero-sequence voltage trajectory analysis for unbalanced distribution networks on single-line-to-ground fault condition. Electric Power Systems Research, 2018, vol. 161, pp. 17-25. doi: https://doi.org/10.1016/j.epsr.2018.03.024.

9. Varetsky Y. Overvoltages in MV industrial grid under ground faults. Energy Engineering and Control Systems, 2019, vol. 5, no. 2, pp. 75-80. doi: https://doi.org/10.23939/jeecs2019.02.075.

10. Bezprozvannych A.V., Kessaev A.G., Shcherba M.A. Frequency dependence of dielectric loss tangent on the degree of humidification of polyethylene cable insulation. Technical Electrodynamics, 2016, no. 3, pp. 18-24. (Rus). doi: https://doi.org/10.15407/techned2016.03.018.

11. Zhu G., Zhou K., Gong W., He M., Kong J., Li K. Inhibition of rejuvenation liquid on trees in XLPE cables under switching impulse voltages. Energies, 2019, vol. 12, no. 11, p. 2133. doi: https://doi.org/10.3390/en12112133.

12. Papazyan R. Concepts for market-based MV cable operations and maintenance using insulation parameters measurements. 2020 12th Electrical Engineering Faculty Conference (BulEF), 2020, pp. 1-5, doi: https://doi.org/10.1109/BulEF51036.2020.9326055.

13. IEC 60287-1-1. 2006. Electric cables - Calculation of the current rating - Part 1-1: Current rating equations (100\% load factor) and calculation of losses - General. $-65 \mathrm{p}$.

14. Aloui T., Amar F.B., Abdallah H.H. Fault prelocalization of underground single-phase cables: Modeling and simulation. International Journal of Electrical Power \& Energy Systems, 2019, vol. 44, no. 1 , pp. 514-519. doi: https://doi.org/10.1016/j.ijepes.2012.07.067.

15. Rozov V.Y., Tkachenko O.O., Yerisov A.V., Grinchenko V.S. Analytical calculation of magnetic field of three-phase cable lines with two-point bonded shields. Technical Electrodynamics, 2017, no. 2, pp. 13-18. (Rus). doi: http://doi.org/10.15407/techned2017.02.013.

16. Kalantarov P.L., Tseytlin L.A. Raschet induktivnostei [Inductance calculations]. Leningrad, Energoatomizdat Publ., 1986. 487 p. (Rus).

Received 14.04.2021

Accepted 22.05.2021

Published 25.06.2021

G.V. Bezprozvannych ${ }^{1}$, Doctor of Technical Science, Professor, I.A. Kostiukov ${ }^{1}$, PhD, Doctoral Student,

${ }^{1}$ National Technical University «Kharkiv Polytechnic Institute», 2, Kyrpychova Str., Kharkiv, 61002, Ukraine, e-mail: bezprozvannych@kpi.kharkov.ua, (Corresponding author),

iakostiukow@gmail.com

How to cite this article:

Bezprozvannych G.V., Kostiukov I.A. A calculation model for determination of impedance of power high voltage single-core cables with polymer insulation. Electrical Engineering \& Electromechanics, 2021, no. 3, pp. 47-51. doi: https://doi.org/10.20998/2074272X.2021.3.08. 